\title{
Chapter 13 \\ The Legal Challenges of Insuring Against a Pandemic
}

\author{
Rachel Hillier
}

\begin{abstract}
COVID-19 has raised, and continues to raise, questions about the traditional approach to insurance cover. For instance, business interruption insurance covering "pandemics" under all risks insurance policies are likely to be a thing of the past. With tensions between businesses and the insurance industry on the rise, what can be done to offer businesses some protection at a premium they can afford, without emptying insurers' reserves? In this chapter we talk about legal challenges related to traditional insurance against the risk of losses caused by a pandemic, and whether parametric insurance is the solution.
\end{abstract}

\subsection{Introduction}

The insurance industry has always been adept at developing insurance products to meet the changing needs of society, from the development of death benefit and personal injury insurance during the Industrial Revolution to motor vehicle insurance in the late $1890 \mathrm{~s},{ }^{1}$ to aircraft insurance in the $1920 \mathrm{~s}$, to drone insurance in the 2010s. The ability to adapt insurance to meet new perils arising from changing human activity is a common thread in the history of insurance.

The COVID-19 pandemic as a new peril is no different. Living with the risk of loss associated with COVID-19 has become a reality and the insurance industry is working to provide financial protection to those affected. However, some of our most established and oldest types of insurance policies have been found wanting during the pandemic, particularly in relation to small businesses hit hard by financial losses during repeated lockdowns and trading restrictions imposed across the world in an attempt to curb the spread of the virus. This chapter looks at the weaknesses and strengths of the legal structure of traditional insurance policies, and how parametric

\footnotetext{
${ }^{1}$ The first motor policies in the UK were written around the time of the original London-to-Brighton car run, which took place on 14th November 1896.
}

R. Hillier $(\bowtie)$

Partner at Capital Law, Cardiff \& London, UK

e-mail: r.hillier@capitallaw.co.uk 
insurance, with the aid of new technologies could assist in providing new insurance to meet the needs of a COVID-19 world.

As a lawyer trained and qualified in England and Wales, I have concentrated in this chapter on challenges to the legal system in England and Wales. However, many other jurisdictions have the same or a similar insurance contracts and therefore similar challenges.

\subsection{Summary of the Traditional Approach to Insurance}

\subsubsection{The Origins of Insurance}

Fire insurance was the start of commercial business insurance in England and can be traced directly to the Great Fire of London in 1666. A company called the "Fire Office" was set up by Nicholas Barbon (a building entrepreneur who made his money rebuilding London after The Great Fire). From 1680, the Fire Office also had a "company of men" to put out the fires. By the 17th Century, marine and life insurance policies were commonly purchased. By this time, the English courts were regularly hearing cases involving insurance disputes. The legal construct of an insurance contract has in many cases not changed significantly since the 17 th Century and is predominantly based on the indemnity principle.

\subsubsection{The Insurance Indemnity Principle}

A definition for a "contract of insurance" is conspicuously missing from the central piece of legislation that regulates the insurance industry in the United Kingdom, the Financial Services and Markets Act 2000 (commonly known as FSMA). This allows the industry to adapt and develop new models of insurance to meet new types of risk. In this section, we will explore why the indemnity principle has become so entrenched in insurance law and why, in many cases, it is not fit for purpose in a pandemic.

Modern insurance has been defined in broad terms by the English courts as "an agreement to confer upon the insured a contractual right which, prima facie, comes into existence immediately when loss is suffered by the happening of an event insured against, to be put by the insurer into the same position in which the insured would have been had the event not occurred, but in no better position". ${ }^{2}$ This definition includes the principle of "indemnity" - that payment under an insurance contract puts the policyholder back in the position they would have been had the event not occurred, but in no better position.

\footnotetext{
${ }^{2}$ Callaghan v. Dominian Insurance Co. [1997]2 Lloyds Rep. 541 per Sir Peter Webster.
} 
The indemnity principle has served the insurance industry well for many years. It is a good tool to ensure that insurers pay only the value of what is lost, so that an insurance policy is not gambling, or merely a security entered into for the purpose of profit.

The fundamental purpose of insurance is to mitigate risk. Risk can be mitigated in many ways. For example, doing business through a limited company can limit the risk of its shareholders to the nominal value of shares owned. Another example is the presence of fire proof doors and smoke alarms in a building to reduce the risk of damage by fire. Mitigation of risk through insurance is achieved through the transfer of risk to another (to insurers and reinsurers). The insurance company ensures it has sufficient reserves from premiums collected from many insureds to protect the few who suffer a loss, so that those few have their losses reinstated, at the expense of all the insureds who paid the insurer their premiums. Thus, risk is transferred to insurers. If the insurer has not collected sufficient premiums to cover the insured losses, it is the insurer that must pay the difference. The insurer must therefore calculate not only the likelihood of a claim occurring, but the likely value of each claim. The indemnity principle provides a good method for insurers to learn from its previous claims as well as to collect information about insured property to build sophisticated models to work out how much each insured is likely to lose on average on an indemnity basis, whilst ensuring at the same time that it does not pay out more than it needs to.

Whilst often convenient to insurers, in the UK, there is no statutory requirement for the indemnity principle to be the basis on which claims are valued, as long as a policyholder has an "insurable interest" in what is being protected. That is, an insured must "benefit by the safety or due arrival of insurable property, or may be prejudiced by its loss, or by damage thereto, or by the detention thereof, or may incur liability in respect thereof". 3

Non-indemnity insurance (including parametric insurance) does exist (and has existed for some years), but such policies are small inlets compared to an ocean of indemnity policies. Section 27(3) of the Marine Insurance Act 1906 provides that an insurance policy may be "valued or unvalued" and that where it is valued, "Subject to the provisions of this Act [...], and in the absence of fraud, the value fixed by the policy is, as between the insurer and assured, conclusive of the insurable value of the subject intended to be insured, whether the loss be total or partial." An example of such insurance is income protection insurance. The amount the insured will be able to claim each month if they are unable to work is fixed in advance, usually with reference to the insured's income at the time the insurance is taken out. There may be some indexed rise in that fixed amount built into the policy, but the agreed payment will be made whether the income actually lost is less or more than the pre-agreed fixed amount.

In the face of new threats to the modern world, such as cyber-crime, climate change and COVID-19, alongside the ability of modern computing power, machine learning and artificial intelligence to provide more accurate model future risks, the

\footnotetext{
${ }^{3}$ Marine Insurance Act 1906, Section 5.
} 
indemnity principle, if not obsolete, may start to lose favour as the primary measure of claims payments in the insurance industry.

\subsection{The Effect of COVID-19 on the Insurance Industry}

On 10th January 2020, the World Health Organization reported that Chinese authorities had determined that an outbreak of a pneumonia type disease, first reported in December in the Wuhan province, was caused by a novel coronavirus, see WHO (2020). The virus spread rapidly into and across Europe. On 23rd March 2020, the UK prime minister, Boris Johnson, announced that people in the United Kingdom must "stay at home" and that non-essential businesses must close.

The closure of manufacturing plants, bars, restaurants, retail establishments, entertainment venues and other places of business resulted in significant business interruption losses and an influx of claims under commercial business insurance policies. But it was not all bad news for insurers. People used their cars less and accidents on the roads reduced significantly, reducing claims under vehicle insurance. Meanwhile, deaths due to COVID-19 spiralled (in June 2020, more than 1,000 deaths a day were recorded due to Coronavirus for 22 consecutive days). The majority of deaths were older people, and many were above the age range for life insurance cover. Yet, the population as a whole was faced with its own mortality, and uptake of life insurance for those who were within normal age ranges for life insurance soared.

\subsubsection{The Effect of COVID-19 on Business Interruption Insurance Policyholders}

When Coronavirus hit, those businesses that had purchased specialist pandemic insurance, for example, the All England Lawn Tennis Club (host of the world famous Wimbledon Tennis Championship) who had learned from the SARS epidemic and taken out specialist pandemic insurance in 2013, did receive payments under insurance policies. However, as they were indemnity based policies, calculating loss was a long and complicated process. Richard Lewis, Chief Executive of the All England Lawn Tennis Club said "It's a wide-ranging policy but part of the reason it takes so long to work through is that everything is looked at, so there's no blanket payout.", Gangcuangco (2020). A Daily Mail report quoted Lewis as explaining "It's looked at line by line quite literally, every cost, expenditure, bit of income, revenue, whether it has to be repaid, all that sort of thing".

Many small and medium sized businesses (SMEs) thought they were covered under their all risks commercial business insurance policies. However, most insurers believed that these policies were not designed to cover a pandemic and there was no cover under them. This dichotomy of understanding between insured and insurer and 
the resulting court cases that ensued across the world have often been in the press during 2020/21. The insurance industry has not covered itself in glory by refusing to pay claims under these policies and taking claims through to the bitter end of the court process in many countries.

In the UK, SMEs complained to the Financial Conduct Authority (FCA) that insurers were refusing the vast majority of claims under all risk business insurance policies. This led to the FCA seeking permission from the UK courts to submit test cases relating to common policy wordings, following widespread concern over the lack of clarity and certainty for businesses. The FCA hoped to obtain some certainty for hard pressed SMEs. The Supreme Court heard the case. It considered a representative sample of 21 types of policy wordings from eight different insurers as test cases. The FCA applied to the court for a decision as to whether the business interruption sections of each policy covered losses due to business interruption flowing from COVID-19 closures. The Court's decisions were broadly in favour of business owners. However, despite that decision, insurers continue to decline claims as policy wordings are often slightly different to those wordings considered by the court. Similar test cases have been considered by courts in other countries across the globe-France, ${ }^{4}$ Germany, ${ }^{5}$ Ireland, ${ }^{6}$ Australia. ${ }^{7}$

Even where insurers have accepted a policy covers economic loss due to the disease, many policy terms have exclusions and conditions that mean claims were legitimately rejected. For example, many policies only cover losses flowing from closure due to the presence of disease on the premises. During the first wave of the pandemic "test and trace" in the UK was not in place, and in the second wave was found to be wanting. Insureds therefore often have difficulty proving that COVID-19 was actually present on the premises and claims were rejected. Even where liability has been accepted, in many cases payments have not been made. Assessment of loss under the indemnity principle is leading to long delays in payment, because not only does the policy wording have to cover the loss event, and causation have to be proved, but loss must also be proved. Seven weeks after the Supreme Court judgement, the UK regulator reported that Hiscox (whose policy wording was considered by the court) had paid just 151 of its customers affected and was still deciding more than 4,500 .

Insurers are vilified in the press, but as Hiscox said in response to criticism, "These are complicated claims that require comprehensive financial information and discussions with customers in order to settle them fairly.", see BBC News (2021). Quantifying economic loss on an indemnity basis is a time-consuming, administra-

\footnotetext{
${ }^{4}$ On 22 May 2020, for example, Paris's commercial court ordered Axa SA unit Axa France IARD S.A. to pay $€ 45,000$ to restaurant group Maison Rostang SAS over the closure of one of its restaurants.

${ }^{5}$ On 1 October 2020 the Munich regional court ordered insurer Versicherungskammer Bayern to pay $€ 1.01$ million to the operator of the Augustinerkeller beer garden.

${ }^{6}$ In October 2020, the Irish High Court heard business interruption cases between insurer FBD Holdings PLC and four pubs.

${ }^{7}$ On 18 November 2020, the NSW Court of Appeal handed down its much-anticipated decision in HDI Global Specialty SE v Wonkana No. 3 Pty Ltd [2020] NSWCA 296 ("HDI Global”).
} 
tively burdensome and costly task, particularly when a once in a life time constantly evolving world-wide pandemic, waxes and wanes, and the same businesses go in and out of lockdown in response pandemic waves (more on the difficulties of quantifying economic loss below). Expecting SMEs to provide detailed evidence of loss in an ever-changing environment of Government led opening and forced closure, whilst they tackle additional and evolving requirements for COVID safe environments and ongoing staff absence due to COVID-19 illness or being required to self-isolate, is creating even further stress on business owners. Many businesses are becoming insolvent and failing before they can prove their losses, even when they have a valid claim.

Ongoing delays and disputes concerning claims for business interruption losses resulting from COVID-19 are happening across the world. For example, in the United States, by August 2020 over 1,000 COVID-19-related insurance coverage lawsuits had reportedly been filed with early outcomes suggesting different judicial interpretations of key issues and limited potential for any consolidation of proceedings, see Covington (2020).

Meanwhile, ongoing loss to SMEs and increased premiums at renewal (as insurers adjust premiums to recoup claims paid and ensure adequate reserves) means many businesses are now finding themselves unable to afford increased premiums without agreeing to large deductibles. Those that can afford cover are often unable to procure insurance against future COVID-19 related losses due to policy terms offered.

\subsubsection{The Effect of COVID-19 on Insurers}

For insurers (and reinsurers), COVID-related business interruption claims have meant many potential losses and uncertainty as to whether policies are valid, affecting levels of reserves required. As of March 2021, publicly available data puts an estimate of total losses due to the pandemic worldwide at $\$ 34.523$ billion, reported in Reinsurance News (2021). However, the use of the indemnity principle as a measure to pay claims means that this figure is an estimate, and the true figures will take years to be known as evidence of economic loss claims is painstakingly gathered and claims are slowly paid. Greater uncertainty as to both liability and quantum means greater uncertainty in traditional claims modelling, resulting in insurers having to hold more cash to top up the reduction in the value of assets held, to meet reserves and regulatory capital requirements.

In my view, the legal costs, and the costs of payments of claims is nothing compared to the reputational damage the insurance industry has suffered as a result of high-profile court cases across the world. Many SMEs have paid substantial premiums for many years, never making a claim, and now feel let down by their insurers in their time of need. This has led to a worldwide loss of faith in the insurance industry by the small business community. Insurance is built on trust, and that trust has been seriously diminished. 
We are now starting to see that many insurers are adding wide ranging exclusions to their all risks business insurance so that SMEs have no cover against further waves of COVID-19. It remains to be seen what the appetite of businesses for renewal of these policies will be, particularly where premiums are increased from the previous year as insurers seek to recover loss.

\subsection{Life Insurance Versus Business Interruption Insurance}

2020 brought an interesting comparison between the fortunes of non-investment life insurance providers and business interruption insurers.

Whilst insurers of business interruption policies have become embroiled in expensive litigation, claims payments have been slow, renewal prices have increased and many insurers have withdrawn from insuring the risk, in comparison, life insurers have been largely unaffected by the pandemic, despite the unprecedented loss of life in 2020. There is no evidence of insurers withdrawing from the life insurance market. Despite high numbers of claims, insurers have not sought to exclude death due to COVID-19, premiums have remained fairly static, many claims have been paid swiftly and life insurance remains a relatively cheap insurance.

Why is that? We all know of the devastating number of deaths due to COVID during 2020. The demographics of those deaths in the UK, according to the Office of National Statistics, is as follows, see Office for National Statistics (2021):

\begin{tabular}{l|c}
\hline Age range & Deaths in the UK as of 27/12/2020 (\%) \\
\hline $0-19$ & 0.06 \\
\hline $20-39$ & 0.63 \\
\hline $40-59$ & 6.76 \\
\hline $60-79$ & 37.98 \\
\hline $80+$ & 54.57 \\
\hline
\end{tabular}

The majority of UK life insurance policies are purchased when individuals take a mortgage and are designed to expire upon mortgage repayment. Although the age at which people repay their mortgages is increasing and of course there are life insurance products available for those in their $80 \mathrm{~s}$, the majority of people have repaid their mortgage and their life insurance policies have ended by the time they reach 80 years. This means the demographics of the COVID-19 death rates have been kind to the life insurance industry. Also, whilst there is no doubt that the number of claims under life insurance has increased, at the same time, life insurers have seen a significant increase in the sale of life insurance, which has meant healthy cash reserves to set off against claims.

There is also a stark difference in the mechanics of life insurance products compared to all risks commercial business insurance. Life insurance is a relatively simple product, not based on the indemnity principle. Policyholders decide at the outset of 
the policy what the payment should be upon the event that is insured-their death. The trigger for payment is simple and easily proved by production of a death certificate. Whilst claims may be investigated where fraud is expected and death due to pre-existing conditions are often excluded, payments are usually made quickly on production of a death certificate. There is nowhere near the administrative burden relating to claims payments, which also keeps premiums lower. There is no ongoing loss - there is either a death, or not a death.

\subsection{Why Existing Indemnity Based Pandemic Insurance Products Are Not Working}

Advances in epidemic risk analytics, including monitoring and modelling tools, have helped insurers better understand their risks and improve response strategies for indemnity based claims. Technology has enabled better risk measurement, monitoring, mitigation and claims management. There are innovative Insurtechs offering tech-based solutions in several areas of indemnity based insurance (UK examples are, Distribind which provides an automated bordereaux system, and Concirrus which uses onboard sensors to provide real time analytics of marine shipping risk). But technology cannot entirely mitigate the time it takes to predict and evidence loss for a new indemnity based risk.

Specialist pandemic insurance was available to businesses prior to COVID-19. In 2018, Marsh McClennan launched a specialist pandemic insurance which provided indemnity based cover, using triggers such as mortality or infections in a defined area. ${ }^{8}$ The policy could be tailored to the policyholder to provide coverage for specific expenses, geographies, types of disease, or portions of a calendar year, but until COVID-19 it reportedly had very little uptake, see Collins (2020). I suspect that the slow uptake was due to the perceived gap in the cost of the insurance compared to the risk of suffering losses due to a pandemic. Hindsight is a wonderful thing, and it must be remembered that the last global pandemic was the influenza pandemic of 1918. Whilst Ebola and SARS were modern epidemics, they were seen in the Western World as foreign diseases of little relevance or risk to communities in the West.

Even for specialist pandemic insurance using the latest technology, the methodology used to determine future loss was not well developed. Insurers had some knowledge of epidemics such as SARs and Ebola, but both were different to each other and each was different to COVID-19. The unpredictability of epidemiology meant that actuaries considering risk models for pandemic insurance were involved in more art than science. Furthermore, modelling of the economic input was based on sparse evidence and on economic simulations rather than empirical data. Unlike natural catastrophes and other crises, pandemics and epidemics typically do not cause

\footnotetext{
${ }^{8}$ https://www.marsh.com/ca/en/press-centre/marsh-to-help-businesses-minimize-financial-lossfrom-pandemics.html.
} 
immediate physical damage, and so they are difficult to model because every business will have bespoke economic loss, dependent on their circumstances at the time.

Then there is the challenge of anticipating behaviour of both governments (severity of lockdowns, enforcement of restrictions, availability of vaccines) and of individuals (super spreaders, mask wearing, social distancing, ability and willingness to work from home).

Most businesses did not hold specialist pandemic insurance, but did hold all risks commercial business insurance which covers any peril in relation to a particular category of risk, unless excluded in the policy. To give an example, an all risks business insurance policy may cover any loss arising from theft, but exclude theft by way of deception, so a break-in would be covered, but fraud would not. This approach to insurance has led to long and complicated insurance policies with many exclusions ${ }^{9}$ and there is often a mismatch of understanding between insured and insurer as to what these policies cover.

Insurers viewed commercial business insurance policies as protection against losses flowing from physical damage to insured premises, subject to restrictions and limitations and that only very few of such policies covered economic loss flowing from COVID-19. For policyholders, they read their commercial business policies as including cover for economic losses relating to closure of their business due to disease and had the expectation that, having paid insurance premiums for years, they would be covered for losses to their businesses flowing from COVID-19.

This mis-match of expectations stems from the nature of all risks insurance policies which started life as simple insurance cover against physical damage to property resulting from fire. Many additions of cover and exclusions over time mean these policies are often repetitive and inconsistent. Add to the mix some unfortunate poor drafting, and it is unsurprising that these types of insurance policies have become a hot bed for litigation in the last year.

Looking at some common policy wordings, you can see why commercial business insurance policyholders had the expectation that they were covered for economic loss flowing from COVID-19:

We shall indemnify you in respect of ...

- interruption of or interference with the business arising from any notifiable disease

- any occurrence of a notifiable disease within a radius of $25 \mathrm{~m}$ from the premises

- the discovery of an organism at the premises which is likely to give rise to the occurrence of a notifiable disease

- in respect of interruption of or interference with the business arising from any infectious disease

- loss resulting from prevention of access to the premises due to the actions or advice of a government or local authority due to an emergency which is likely to endanger life or property

\footnotetext{
${ }^{9}$ For example, the RSA business combined policy is 72 pages long.
} 
- loss of income arising from the closure or restriction in use of the premises by a competent local authority due to defects in the drains or other sanitary arrangements or discovery of vermin or pests at the premises

- damage to Property or premises within one mile of the boundary of Your Premises which causes a loss of Income directly due to a reduction in customers visiting the area."

Reading the extracts above, you could be forgiven for siding entirely with the policyholders making claims for losses during the COVID-19 pandemic. But all-risks policies will also have exclusions, for example,

- Any pandemic coronavirus or strain identified by the World Health Organization.

- Any loss or damage directly or indirectly caused by or contributed to by or arising from contamination.

One of the biggest areas of dispute in COVID-19-related business interruption claims is whether COVID-19 has caused damage to business properties from which economic loss flows. This is because most indemnity based business insurance policies have, at their core, the principle that the insurance covers loss flowing from physical damage. However, over time additional cover against economic loss has been added, such as economic loss due to closure by a local authority and in amongst the list, often loss arising from interruption of trade due to closure of the premises on the occurrence of disease, either on or near the premises. Policyholders argue that COVID-19 has damaged their business and their premises and so they are covered when they have to close as a result.

Where claims were made on the basis that COVID-19 had physically damaged the premises, the insurers' arguments against this were varied and included:

- The presence of invisible microbes on surfaces or objects, however, potentially injurious to human health do not amount to physical damage to the property, and the policy only covers loss flowing from such physical damage.

- COVID-19 microbes cannot be said to alter the physical state or condition of surfaces or objectives whether at surface level or molecular level, so there cannot be physical damage.

- Even if COVID-19 were to be held to be physical damage, it can be removed by deep cleaning, and even if left individual microbes dissipate after between 18 and $100 \mathrm{~h}$, so it is not permanent.

- A deposit of something on property (i.e. the COVID-19 virus) which causes no physical alteration to the property itself does not equate to damage to that property.

Where the words "physical damage" are used, insurers felt they had a strong case and this has been born out in recent case law. ${ }^{10}$ However, some policies refer only to

${ }^{10}$ TKC London Limited v Allianz Insurance plc [2020] EWHC 2710 (Comm). 
"damage", and so the argument then is, whether COVID-19 has caused "damage" to the business.

Where policies clearly and separately include cover for loss flowing from business interruption due to closure because of disease, insurers have argued as to the meaning of "disease", "notifiable disease", and "human disease". Many wordings refer to "notifiable disease", but it is often not defined. Medical practitioners must report "notifiable diseases" to the government under statutory duties in the Public Health (Control of Disease) Act 1984 and the Health Protection (Notification) Regulations 2010, and on 5 March 2020, COVID-19 was added to the list of notifiable diseases. Where notifiable disease is not defined, is that what was meant? Some policies are even more vague — referring only to "human disease" or just "diseases", particularly with reference to local authorities shutting businesses down.

Cover often includes losses due to "closure by an authority" because of disease. Insurers have argued that an "authority" relates to a local authority, and it was the UK Government, Welsh Government and Scottish Government that initially "advised" and then required businesses to close, so there is no cover.

For good measure, where policies do not specifically exclude loss due to a pandemic, insurers argue that commercial business insurance simply is not designed to cover pandemics and that policyholders must have realised that when they purchased the insurance, because of the price of the premium. Whilst the concept of applying a construction of a policy that makes commercial sense for both parties is established law, in my view raising such arguments both in court and in the press, does nothing but harm the reputation of the insurance industry.

Where primary liability is proved by the insured, under the indemnity principle, policyholders then have to prove causation between the insured event that has occurred and the economic loss suffered. This principle has led to further disputes between the insurer and the insured, particularly in relation to economic damage suffered by SMEs during lockdown due to the presence of COVID-19 on or near the insured premises. Insurers have argued that in many cases, the economic loss of businesses has been caused by a national lockdown and an economic downturn, not by the presence of COVID-19 on the premises. Insurers have required evidence from their insureds of COVID-19 physically being present on the premises, which, particularly during the first wave of COVID-19 is impossible for most as testing was not widely available and there was no means of tracing where infected people had been. Even where COVID-19 on the premises could be proved, policyholders had to show that this caused the closure of the premises and that such a closure would not have happened irrespective of the COVID-19 instance on their premises. In many cases this is an impossible hurdle to climb.

A perfect storm has brewed between insurers and their policyholders. It is not that the insurers are the corporate bad guys, and nor do the policyholders have unrealistic expectations of cheap property based insurance. The problem is the structure of the indemnity policy, which does not meet the fundamental needs of risk transfer in a pandemic. It is little wonder that insurers are choosing to change policy wordings on renewal to remove all cover for losses related to disease, COVID-19 or otherwise. 
This is not a UK only issue. Businesses across the world have been hit by the pandemic. In the United States, Charles Chamness, president of the US insurer's trade association, National Association of Mutual Insurance Companies (NAMIC) has been quoted as saying "Pandemics simply are not insurable risks; they are too widespread, too severe and too unpredictable for the insurance industry to underwrite”, see Insurance Journal (2020).

\subsection{Proposals Across the World for Resolving the Business Interruption Insurance Deficit}

Across the world, governments and insurers have established working groups to consider proposals for future insurance of business interruption losses resulting from a pandemic. Considerations have included incentivising risk prevention measures, using different models of risk transfer between insurers, reinsurers and governments, see EIOPA (2020), and charging a flat rate levy in all insurance products to create a central fund to be paid to commercial businesses in the event of a World Health Organization declared pandemic, see GDV (2020).

Parametric solutions are also being considered:

1. The French, Fédération française de l'assurance, have devised a parametric solution providing coverage for business interruption losses resulting from various pre-determined catastrophies (e.g. terrorist attack, pandemic, natural disaster). Cover will be triggered by state action to close businesses. Payments will be fixed lumps sums, not indemnity based claims, but will be "calibrated" to replace gross business disruption costs net of salaries and profits, see FFA (2020).

2. In the United States, insurers and the Federal Government are considering the development of a national parametric solution. A formulaic payout is proposed to be made to businesses, triggered by a presidential declaration of viral emergency. Businesses would choose the desired level of protection for three months relief of up to $80 \%$ of their payroll. Businesses would purchase the insurance via stateregulated insurance entities. Aid would come from the Federal Government, see Insurance Journal (2020).

\subsection{What Is Parametric Insurance?}

Parametric insurance is not a new phenomenon. For around 20 years, insurers have used parametric triggers in relation to catastrophic events such as flooding, hurricanes and earthquakes, and it has been used successfully to write policies relating to Ebola and Zika outbreaks. Parametric insurance (also called index-based insurance) is a "pre-valued" policy. Pre-agreed payments are made upon a trigger event occurring. 
Trigger events depend on the nature of the parametric policy and can include environmental triggers such as wind speed and rainfall measurements, see Molini et al. (2007). Previously, it has been used to protect the agriculture industry against losses due to catastrophic weather events, because the level of actual losses affecting often large areas of the world are not viable for indemnity insurance. Payments are linked to a pre-agreed index, which is linked to loss of production. For example, rainfall in a particular area. Where rainfall falls below a certain level (drought conditions) or over a certain level (flood), pre-set payments are "triggered". Payments are automatically paid upon the trigger event occurring at a pre-agreed amount.

Smart contracts are often used. These are usually associated with block chain technology, but are not exclusive to it. Smart contracts are self-executing contracts, so the agreed amount is paid automatically in accordance with written lines of computer code.

To work well, parametric insurance requires the following:

(1) a recognised and trusted set of data which both parties to the contract agree to rely on;

(2) a pre-agreed payment figure, which may or may not be linked to various levels of data; and

(3) a clearly defined event which acts as a trigger;

(4) an acceptance by the insured in clear terms that payments may not (and probably will not in most cases) put the insured back in the position they had been before the trigger event.

\subsubsection{Working Examples of Parametric Insurance}

\subsubsection{Case Study 1-Flooding}

The insurance need: flood damage to commercial premises in flood prone areas. The UK is experiencing increasing flood events. According to a study from Heriot-Watt University, flooding in the UK could increase by an average of $15-35 \%$ by 2080 , see Ellis et al. (2021). Many businesses who have previously suffered flood damage or are located in an area at risk of flooding find it hard and sometimes impossible to find indemnity based insurance to protect their property from flooding at a premium they can afford.

An Insurtech parametric solution: FloodFlash ${ }^{11}$ uses an internet connected flood depth sensor which is fixed to the premises. The insured chooses a depth of flooding (for example, $0.5 \mathrm{~m}$ ) which will trigger payment under the insurance policy. The insured also chooses the sum they want to receive when the sensor notifies Floodflash

\footnotetext{
${ }^{11}$ Flood Flash—rapid payout flood insurance for any business.
} 
that the trigger is met. The premium for insurance is calculated using the depth trigger and the agreed settlement amount. Payment of the pre-agreed settlement figure is made to the insured automatically within hours of the trigger being met. Several triggers can be set, for example, a payment of $£ 50,000$ is triggered when the water depth reaches $0.5 \mathrm{~m}$, then a payment of a further $£ 50,000$ is triggered when the water depth reaches $1.2 \mathrm{~m}$.

Why it works: The payments are swift, but are usually less than the cost of recovery from the flood as the insured will set the flood depth trigger and the settlement amount to the amount of premium it can afford. Fast payment often means that businesses can use the settlement as a "first responder" pot of money to get the business trading again. For the insurer, meteorological predictions have become more sophisticated so that flood events can be predicted more accurately, and the level of payment is already set, meaning risk can be better measured, and significant claims and loss adjuster costs are negated. The insurer can offer smaller settlement amounts on risks it would reject for insurance on an indemnity basis.

\subsubsection{Case Study 2-Earthquakes}

The insurance need: Insurance for households against losses due to earthquakes in areas of high earthquake risk areas. In the United States, damage caused by earthquake is not commonly included in household insurance policies. Where it is available, traditional indemnity based insurers require large deductibles, because otherwise the premiums are too high to be affordable. When there is an earthquake there are many claims at once and it takes time to process. Where there is catastrophic damage, insurance often pays for replacement accommodation whilst rebuilding takes place, but for lower level damage insurance payments are slow.

An insurtech meeting the needs of customers through parametric insurance: Jumpstart Recovery ${ }^{12}$ uses its tech platform to monitor data from the United States Geological Survey (USGS) Shake Maps. When peak ground hits a velocity of $30 \mathrm{~cm}$ per second in a certain area, the USGS turns its Shake Map red in that area. This triggers the Jumpstart platform to automatically send a text to its policyholders whose properties are insured in the area that turns red, asking if they have suffered a loss. The insured texts "yes" in response, and $\$ 10,000$ is automatically sent to the insured's bank account.

Why parametric insurance is a good solution: This is a great example of parametric insurance providing a fast effective solution to a large amount of low level losses arising from one catastrophic event. It is a first responder type insurance which provides fast payment to cover immediate losses. It is not a replacement for more comprehensive indemnity based insurance against the cost of rebuilding, but either compliments it, or provides lower level risk transfer for those who cannot afford the "bells and whistles" of full indemnity based insurance.

\footnotetext{
12 https://www.jumpstartrecovery.com/.
} 


\subsubsection{Challenges}

There are challenges to the use of parametric insurance for business interruptions policies.

\subsubsection{Triggers and Quality of Data}

Parametric insurance is hugely dependent on the basis of the trigger used for payment. There needs to be confidence on the part of both the insured and the insurer in the veracity of the data. By veracity I mean the accuracy and truthfulness of the data being used, as well as the ability of the insured, and potentially a court, to verify the truth of the data and that the trigger has been fired in the correct circumstances.

Some parametric insurance terms rely on more than one data point. For example, the World Bank Pandemic Emergency Financing Facility's parametric catastrophe bond $^{13}$ relies on publicly available data to determine how much money the facility would release to the poorest countries in the world. According to the World Bank, the triggers are based on outbreak size (the number of cases of infections and fatalities), outbreak growth (over a defined time period), and outbreak spread (with two or more IBRD/IDA countries affected by the outbreak). Pay-out occurs only after a slew of conditions are met in connection with a country: (1) a rolling daily average of at least 250 cases; (2) the virus exists for at least 84 days; (3) total confirmed deaths to be greater than 250 cases (for class B issuances) or 2,500 cases (for class A issuances); (4) an exponential growth rate; and (5) geographic spread of the virus. The World Bank was criticised by the Financial Times, see Financial Times (2020), for making the parametric triggers so high that it was nearly 40 days after the World Health Organization officially announced that COVID-19 was a pandemic, before the first payments were made. The more data points relied on, the more chance there is of the trigger being in dispute.

Statistical parameters could be used, relying on third parties to determine whether a trigger has been satisfied. Such triggers are typically utilised in catastrophe bonds and insurance-linked securities (instruments connected to insurance-related risks that provide issuers funding for specific events), where scientific measurements of the severity of tornadoes or hurricanes are used. Third party analytics of infection rates or death rates in a particular area could be used as a trigger for pandemic insurance.

The epidemic data analytics firm Metabiota has also developed the Pathogen Sentiment Index, Metabiota (2018), that measures the effects of changes to behaviour in a pandemic, giving "fear" score based on disease attributes, symptoms and mortality, disease transmission and availability of treatment, to provide a score to reflect reduction in consumption. Others are based on an index of available data to determine when the policy pay-outs can begin. Some pandemic insurance has used the rate of

\footnotetext{
${ }^{13}$ A financing mechanism used at the World Bank (https://www.worldbank.org/) is designed to provide an additional source of financing to help the world's poorest countries respond to crossborder, large-scale outbreaks.
} 
hotel bookings in comparison to year-on-year averages or the measures of footfall in pedestrian areas.

My view is that for a pandemic business interruption solution for SMEs, a simple single trigger should be used and would mean a faster rollout of the product and more transparency for the policyholder. While using several third party behaviour-based metrics are useful for international organisations where a more sophisticated trigger for difference areas of the business is needed, for SMEs a single parametric trigger relying on one datapoint would be preferable where there are many smaller claims.

Civil authority triggers could be a solution. However, the challenge for insurers is to pick which civil authority trigger to use in a rapidly changing political response to a novel situation. In the UK, the Health Protection (Coronavirus, Restrictions) (All Tiers) (England) Regulation 2020 came into force came into force on 2nd December 2020. This legislation introduced the concept of "tiers" and has been updated and amended several times during as the pandemic has evolved and our knowledge of how the disease spreads has increased. These regulations have been made under Section 45 of the Public Health (Control of Disease) Act 1984, which allows UK Government to make a regulation "imposing or enabling the imposition of restrictions or requirements on or in relation to persons, things or premises in the event of, or in response to, a threat of public health". ${ }^{14}$ A specific trigger regarding the implementation of regulations restricting access under this Act could be used, but then the devolved nature of the United Kingdom means that the Welsh and Scottish Government have devolved powers to make these regulations, so this would only work for England unless the Welsh and Scottish regulations were added to the trigger. There is also the issue of "Guidance". In the early stage of the pandemic, the UK Government issued guidance that people should stay at home, severely impacting the entertainment and leisure industry, despite there being no regulation in place.

An alternative trigger would be infection rates in a particular area. There are potential difficulties with how these figures are arrived at: in the UK they are based on the percentage of people who have tested positive for COVID-19 at a point in time, but an alternative trigger might be the incidence rate-a measure of only the new infections in a given period of time. This trigger relies on a good testing regime. We know that at the start of the pandemic in the UK, testing was not well developed, and it is widely accepted that infection rates were far higher in reality compared with the figures recorded.

\subsubsection{Pricing Challenges}

For insurers, it will be a continuing challenge to build a risk model that can price premiums that are affordable and get the ratio right between premiums and claims payments. Can AI, machine learning help? Do we trust it enough? There are developments in this area which could help. US Insurtech, Thimble, joined the 5th cohort of Lloyds lab accelerator programme in 2020, Lloyds Lab (2021). Thimble is using

${ }^{14}$ Section 45C(3)(c) of the Public Health (Control of Disease) Act 1984. 
AI to devise a parametric business interruption insurance policy that has low limits before payment is made, and pays out incrementally and instantly, for example where businesses in a certain zip code are forced to close. There is certainly more that can be done in this area and Insurtechs continue to work on solutions.

\subsubsection{Legal And/or Regulatory Uncertainty}

Few countries have specific laws or regulations about parametric insurance. Whilst parametric insurance is an accepted concept in many countries, it can cause uncertainty as to lawfulness in jurisdictions where the indemnity principle sits at the core of insurance law and regulation. For example, in India and South Africa parametric insurance is often purchased by farmers in relation to drought and flood. The law in India around contingency based agreements means that the insured must prove a loss to the insurer. This requirement means that when a trigger is met, there is then the same slowness in claim payments under parametric insurance, as for traditional insurance. South Africa similarly has legal requirements for the insured to prove loss, but has approached the issue in a different way, by not requiring the insured to prove the extent of loss, only that some loss has occurred. Countries where parametric insurance is now well established includes the United States, many African states, the UK, France and the Caribbean.

\subsubsection{Opportunities}

\subsubsection{Combination Policies}

There is room for a combination parametric/indemnity policy. This would be a means of indemnifying against loss to a certain extent, but it would also provide an immediate parametric based payment as a first response. I am not aware of a single insurance policy that provides both options at the time of writing.

\subsubsection{Combining Parametric Insurance with Government Support}

Parametric insurance could be a simple method of providing a combination of Government support and insurance claim payments. In the UK, Government has worked with insurers in relation to flooding loss (Flood Re). Flood Re is a joint initiative between the UK Government and insurers. All home insurance companies in the UK pay a levy to Flood Re, which is a reinsurer set up for the purpose. All those insurers can then use Flood Re to reinsure the flood risk part of a policy where a home is in an area that is at higher risk of flooding, so providing a transfer of risk where insurance might otherwise be refused. A scheme could be implemented at Government level 
where payments triggered by parametric technology are be partly insurance funded, partly government funded.

\subsubsection{Capital Investment}

Insurance has not typically been attractive to capital markets as part of an investment portfolio. Insurance linked securities (ILS) are traded, but are not a main stream investment. The clean transparent nature of parametric insurance is likely to be more attractive, as investors only need to understand the event trigger, not potential quantum (as payments are always a pre-valued fixed sum). It could be that as parametric insurance grows in popularity insurers/reinsurers can hedge against risk aggregated exposure to parametric triggers with parametric ILS securities, thereby transferring the risk of a pandemic to some extent away from government and insurers/reinsurers to capital markets and institutional investors.

\subsubsection{Could Parametric Insurance Be the Answer for SMEs During a Pandemic?}

Parametric pandemic insurance could be the solution as a "first defence" against business interruption during a pandemic. For larger businesses it may well be that both a parametric insurance product and a more specialist traditional indemnity based pandemic insurance policy are the way forward. However, for the many SMEs in the UK and the rest of the world, for whom a huge protection gap has emerged, parametric insurance could be the only affordable option.

In the same way as a paramedic being first on the scene of an accident can make the difference between life and death in the aftermath of an accident, payment within $48 \mathrm{~h}$ of forced closure to a pandemic, could mean the difference between business survival and closure. The paramedic is very quickly available to give life-saving aid with enough equipment and enough training to keep those involved alive. The treatment does not cure the victims of their injuries, but it is enough to keep them alive, to relieve some of the pain, and to give comfort until the ambulance arrives with more equipment and the injured is taken to hospital for more thorough treatment and hopefully a full recovery. Parametric business insurance can work in the same way, providing fast, automatic payment with no requirement for proof of loss, upon a mutually agreed trigger associated with the pandemic that affects that business. Furthermore, parametric insurance allows those fast automatic payments to be made repeatedly, every time a prescribed trigger event occurs.

The payment is unlikely to indemnify all losses, but will be enough to keep the business alive in the immediate crisis so that it does not fail, but lives to trade another day. That initial payment may be enough to purchase necessary PPE and change the premises to meet social distancing requirements, or may pay for fixed 
cost commitments such as rent/salaries during lockdown or reduced trade due to social distancing measures.

Causation is taken out of the equation in a parametric solution. All the problems that business owners have experienced under indemnity business interruption policies are gone: complicated terms, having to prove their losses are caused by COVID-19 being on or near the premises, lengthy waits for payment. It does not matter whether losses are due to a general downturn, poor management or COVID-19, the agreed sum is paid automatically.

Parametric insurance is not only good for the insured. For insurers, it significantly reduces the administrative claims burden and allows for smaller pay-outs in return for payments policyholders can afford. An army of loss adjusters and claims handlers are not required. Payments are made automatically when data feeds from the agreed source hit the trigger. There is no requirement to assess or prove loss.

\section{References}

BBC News, D. Ascher, It's do or die time for my insurer to pay up, 29 March 2021, https://www. bbc.co.uk/news/business-56535583

S. Collins, Insurers wary of meeting growing demand for specialist pandemic cover. Commer. Risk, 9 April 2020, https://www.commercialriskonline.com/insurers-wary-meeting-growing-demandspecialist-pandemic-cover/

Covington. Developments in Coronavirus coverage litigation and legislation, Covington \& Burling LLP, 13 August 2020, https://www.cov.com/en/news-and-insights/insights/2020/08/ developments-in-coronavirus-coverage-litigation-and-legislation

EIOPA. Issues Paper on resilience solutions for pandemics. European Insurance and Occupational Pensions Authority (2020), https://www.eiopa.europa.eu/content/issues-paper-resiliencesolutions-pandemics_en

C. Ellis, A. Visser-Quinn, G. Aitken, L. Beevers, Quantifying uncertainty in the modelling process; future extreme flood event projections across the UK. Geosciences, 11(1), 33 (2021), https://doi. org/10.3390/geosciences11010033

Fédération Française de l'Assurance (FFA). La Fédération Française de l'Assurance présente sa contribution au débat sur la création d'un régime de catastrophes exceptionnelles: le dispositif CATEX, Fédération Française de l'Assurance, 2020. https://www.ffa-assurance.fr/actualites/lafederation-francaise-de-assurance-presente-sa-contribution-au-debat-sur-la-creation-un

Financial Times, A. Gross. World Bank pandemic bonds to pay $\$ 133 \mathrm{~m}$ to poorest virus-hit nations, 19 Apr 2020, https://www.ft.com/content/c8556c9f-72f7-48b4-91bf-c9e32ddab6ff

T. Gangcuangco, Outgoing boss lifts the lid on Wimbledon's pandemic insurance. Bus. Insur. UK, 29 June 2020

Gesamtverband der Deutschen Versicherungswirtschaft (GDV). Green paper: Supporting the economy to better cope with the consequences of future pandemic events (2020), https:// www.en.gdv.de/resource/blob/59854/079826b589006ed3bd4fc7a09e64cf1a/pandemiefondsvorschlag-download-green-paper-data.pdf

Insurance Journal. Insurers, Agents Propose Pandemic Business Relief Plan; Plaintiff's Offer BIG Compromise, May 22, 2020. https://www.insurancejournal.com/news/national/2020/05/22/ 569611.htm

Lloyds Lab. Cohort 5: InsurTech solutions to support COVID-19 response, recovery and futureresilience (2021). https://lloydslab.com/insurtechs/cohort-5/ 
Metabiota. Infectious disease outbreaks can inflict enormous social and economic disruption (2018). https://metabiota.com/sites/default/files/presentation_files/Metabiota\%20Pathogen \%20Sentiment\%20Index\%20Flyer_Apr\%202018.pdf

V. Molini, M. Keyzer, B. van den Boom, W. Zant. Creating safety nets through semi-parametric index-based insurance: a simulation for Northern Ghana, in European Association of Agricultural Economists. 101st Seminar, Berlin Germany, 5-6 July 2007. https://EconPapers.repec.org/ RePEc:ags:eaa101:9263

Office for National Statistics (ONS). Latest data and analysis on coronavirus (COVID19) in the UK and its effect on the economy and society, https://www.ons.gov.uk/ peoplepopulationandcommunity/healthandsocialcare/conditionsanddiseases

Reinsurance News. COVID-19 loss reports and reserves reported by insurance or reinsurance companies. Reinsur. News, April 2021. https://www.reinsurancene.ws/covid-19-insurer-reinsurerloss-reports/

WHO. Timeline: WHO's COVID-19 response, https://www.who.int/emergencies/diseases/novelcoronavirus-2019/interactive-timeline\#event-7

Open Access This chapter is licensed under the terms of the Creative Commons Attribution 4.0 International License (http://creativecommons.org/licenses/by/4.0/), which permits use, sharing, adaptation, distribution and reproduction in any medium or format, as long as you give appropriate credit to the original author(s) and the source, provide a link to the Creative Commons license and indicate if changes were made.

The images or other third party material in this chapter are included in the chapter's Creative Commons license, unless indicated otherwise in a credit line to the material. If material is not included in the chapter's Creative Commons license and your intended use is not permitted by statutory regulation or exceeds the permitted use, you will need to obtain permission directly from the copyright holder.

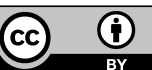

